\title{
How Much Voice for Borrowers? Restricted Feedback and Recursivity in Microfinance
}

Article by an MPIfG researcher

Philip Mader: How Much Voice for Borrowers? Restricted Feedback and Recursivity in Microfinance. In: Global Policy 8(4), 540-552 (2017). Wiley-Blackwell

The original publication is available at the publisher's web site: https://doi.org/10.1111/1758-5899.12474

\section{Philip Mader}

\section{Institute of Development Studies, Brighton}

\begin{abstract}
This paper studies the governance of microfinance and asks about its recursivity: whether the system is responsive to changes prompted by feedback from borrowers or not. It draws on Hirschmann's heuristic of exit and voice and the idea of participation in development, to examine three channels of feedback from borrowers to rule-makers and ask to what extent they have facilitated or restricted recursivity in microfinance. The standardisation of microfinance along a financial template is shown to have created very open flows of financial information, useful for monitoring clients' exit, but not granting them voice. The more recent creation of systems for social performance management and pursuing 'responsible' microfinance, however, has not resulted in similarly robust information flows, because, despite intentions to capture client satisfaction and feedback, these channels are severely restricted. They offer borrowers little chance to practically exercise voice and convey feedback which affects the rules. Recursivity studies, it is suggested, might integrate participation and exit/voice frameworks to explore the prospects of feedback from grassroots rule-subjects and better understand the factors that can restrict it. For microfinance, it is suggested that government regulation and clients' collective action could be necessary where the sector's governance system shows itself to be unresponsive.
\end{abstract}

\section{Policy Implications}

- Microfinance, as presently conceived, is a top-down financial intervention with little scope for participation and voice for clients, which has made it rigid and even potentially harmful to borrowers.

- Support for organisations which represent borrowers more directly, such as debtors' associations, could be more effective than continuing with fraught efforts to channel borrower voice within the microfinance industry.

- Donors can support indigenous or grassroots financing initiatives (e.g. cooperatives) as alternatives to create competition that indirectly pushes the microfinance industry to be more responsive.

- Government regulation for client protection - if need be including interest rate caps, rules prohibiting lending to particularly vulnerable clients, and restrictions on strong-armed collection practices - should be implemented and strengthened.

\section{Recursivity, participation, and voice}

The concept of recursivity describes possible reciprocal interactions between regulators and regulatees, and more broadly between the making of rules and their implementation, when feedback triggers their revision. This paper contributes to the study of recursivity through an examination of microfinance, which, like many other programmes for development, is premised on the idea that interventions from 'outside' can create favourable changes in the environments and lives of poor people. The idea of 'participation' in development, however, has challenged such a fundamentally top-down logic and insisted that the voices of 'beneficiaries' and their local knowledge must inform development programming. Participation has become deeply inscribed into the development mainstream since the 1990s, as scholars and activists have demonstrated repeatedly that the designers and implementers of development programmes 'outsiders', often from the global North, or members of domestic urban elites - are usually deeply ignorant of the circumstances that poor people, particularly in rural areas, live in. Therefore, the latter must be allowed and enabled to participate in - or better yet shape - development interventions, both as a route to programme improvement and as an intrinsic right (Chambers, 1997).

Participation is understood here with Chambers (1994, p. 2) as 'an empowering process which enables local people to do their own analysis, to take command, to gain in confidence, and to make their own decisions'. This may seem a tall ask for microfinance; but it squares with popular depictions of microfinance as an intervention that 'recognizes that poor people are remarkable reservoirs of energy and knowledge [and microfinance therefore has] an untapped opportunity to create markets, bring people in from the margins and give them the tools with which to help themselves.' (Kofi Annan, cited in Brown 2010). Meanwhile, these notions of hearing and including the knowledge of poor people echo more recent conceptions of recursivity in governance, wherein feedback from 'below' triggers the revision of rules (Malets and Quack, this volume). In both participation and recursivity, the idea is that systems which give rule-subjects a chance to shape the rules are more adaptive 
and appropriate. Taken together in this way, participation and recursivity suggest development initiatives should be deliberative and foster debate and exchange among their intended beneficiaries to inform changes in development practitioners' designs (Heller and Rao, 2015).

So what voice or deliberation regarding its rules does the microfinance sector grant its clients? As will be shown, not much; clients' opportunities to participate and shape the rules governing microfinance are presently very restricted, as will be elucidated with reference to Hirschman's (1970) notions of 'exit' and 'voice'. Hirschman's iconic framework itself ought not to require much further clarification; it is widely known and has been amply discussed and employed in the social sciences. 'Exit' and 'voice' are used here as simple heuristics for potential forms of communication about satisfaction or dissatisfaction that members or clients of an organisation - in this case people who borrow from microfinance institutions (MFIs) - have recourse to.

- As the opposite of borrowing and repaying dutifully (which lenders may take to signal satisfaction), exit in microfinance means that clients choose not to borrow, or force a standoff with lenders by not repaying. Effectively, an MFI registers client exit in three ways: through low demand to start, through non-repayment of loans, or through clients 'dropping out' (not borrowing again). If clients exit, this can impel MFIs and their apex organisations, which make many of the rules for MFIs, to seek to understand their grievances better and develop new solutions.

- Voice in microfinance means clients providing - and being allowed to and enabled to provide - meaningful input and feedback regarding the service vis-à-vis MFIs. Voice can offer MFls more direct insights the nature of clients' grievances and possible solutions, conveying to rule-makers how the rules currently inadequately reflect the needs or demands of the rule-subjects. Voice could clarify whether it is, for instance, too high charges, too rigid repayment modalities, or a lack of ancillary services that makes clients unhappy.

- Hirschman's third notion, loyalty, is not applied here. It would warrant a separate discussion in light of the diminished choices which indebted clients have. A severely indebted client may, effectively, be forced to borrow (rendering the concept of 'loyalty' hollow).

'Restricted' recursivity, as discussed here, does not so much suggest complete blockage as rather a severe narrowing of the scope of possible voice. In microfinance, upward flows of information do exist, but because microfinance is a financial industry, these are primarily financial channels, through which 'money talks'. The main opportunity that borrowers have to affect the rules of microfinance is through exit: not participating, or resisting repayment. If borrowers have only the binary take-it-or-leave-it exit option, rather than opportunities for exercising meaningful voice, this precludes recursivity. However, recent efforts to institute 'social performance management' and 'responsible microfinance' have appeared to change this, appearing to give borrowers more voice. But as seen below, these remain severely restricted as channels for recursive feedback, by being too weak and poorly designed to counteract the strong financial channel.

The following section will map the actors, concepts, institutions and forms of rules in the transnational governance of microfinance. Section 3 examines the sector's governance over three historical stages (each of which reflects a distinct feedback channel): the standardisation and scaling-up of microfinance as a financial system, the creation of 'social performance management' systems, and the shift to 'responsibility' as a possible new guiding concept for microfinance. Section 4 concludes with lessons for microfinance and seeks to generalise about the 'restricted' type of recursivity.

\section{Governance characteristics of the microfinance field}

Characterising microfinance as a governance field that lacks adequate feedback channels may be somewhat surprising, given how it is often perceived as a homegrown development model from the global South. The microfinance sector is famous thanks to a handful of iconic organisations like the Grameen Bank from Bangladesh, which won the 2006 Nobel Peace Prize together with its founder Muhammad Yunus. But despite its grassroots image, the basic shape of modern microfinance largely stems from the mould of Northern institutions which picked up the concept and transformed NGOs into financial institutions. Contrary to the sector's public image, microfinance today is predominantly a for-profit activity; almost three quarters of lending is done by explicitly for-profit organisations ${ }^{1}$, and many organisations that have remained NGOs or non-profits also follow a profit-generating lending methodology. Although clients are often referred to as 'members', MFIs generally operate more like retail financial institutions than NGOs or member-based organisations. They disburse loans to clients (or groups of clients) primarily on the basis of their presumed likelihood to repay, not social considerations. Another fact that runs contrary to popular perceptions is that many microloans are not used for microenterprise, but instead for consumption and other non-business needs; some sector leaders acknowledge that as many as 90 per cent of microloans may finance current consumption instead of enterprise (Beck and Ogden, 2007). Very importantly, despite the growing rhetorical emphasis by microfinance leaders on other services like savings, insurance, money transfers, the dominant activity of microfinance sector remains microcredit (Mader 2015).

Microfinance grew from humble beginnings among local NGOs in South Asia and Latin America in the 1970s and 1980s into a donor darling and a global financial industry by the late 2000s, counting as many as 3,718 microfinance institutions (MFIs) with around 200 million clients and loans amounting to more than US\$100 billion (Reed, 2014). ${ }^{2}$ As shown in Figure 1, the sector expanded very through its transformation into a financial industry. Many MFIs operate in only one country, but many important ones are part of 
Figure 1. Growth of the transnational microfinance industry

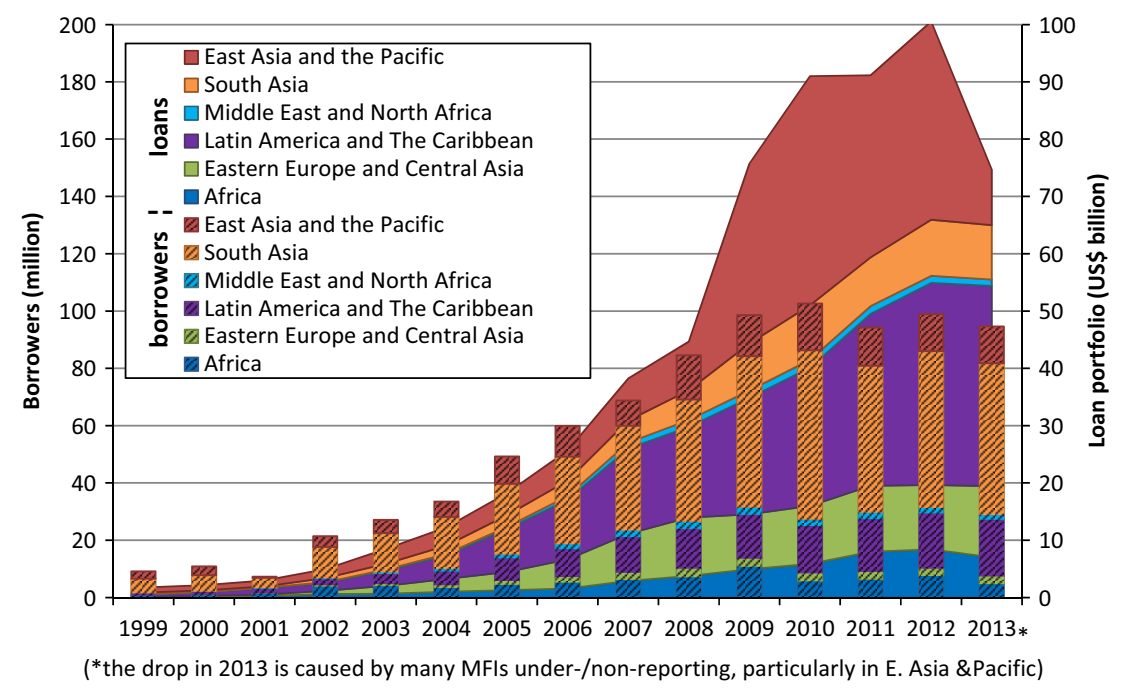

Source: Microfinance Information Exchange (MIX).

larger networks that span multiple countries. Funding comes from all over the world, and most cross-border funding comes from the global North.

Because there are no organisations large enough to be dominant or even representative of 'microfinance', this paper will consider the governance of the global microfinance sector as a whole. How then to map this global field and the processes of recursivity that might play out in it? Terence Halliday and Bruce Carruthers (2007) suggest a framework for analysing the global recursivity of law, specifically the diffusion of bankruptcy regulation. This lends itself to studying microfinance, as another cross-border field involving rules and systems for managing financial obligations. Halliday and Carruthers highlight the importance of four interconnected dimensions: the actors on the rule-making and the rule-implementing side, the constitutive power of concepts, the key institutions involved in rule-making, and the form of the rules. These are introduced here for microfinance in turn.

\section{Actors}

Microfinance is a complex and multi-layered industry which cannot easily be schematised. However, from a governance perspective, those who have a stake in the rules governing it may be grouped in six broad categories, the first three of which tend to be rule-makers:

1. Funders - a variety of actors are involved, including private individuals, large commercial investors and banks, specialised investment funds, government bodies and international development banks. The bulk of invested capital (\$21.5 billion out of at least $\$ 29$ billion) comes from public coffers (Dashi et al., 2013), although private funding is on the rise. Funders have the financial clout to shape the rules and premises of microfinance.
2. International organisations - some international development bodies are major funders, but importantly they also provide advisory services and capacity-building for MFIs, coordinate among MFIs and other funders, and liaise with governments, for instance on issues of regulation. Key actors are the World Bank (and its sub-organisation Consultative Group to Assist the Poor, CGAP; discussed below) and other multinational development agencies such as the Inter-American Development Bank, as well as national development agencies such as the United States Agency for International Development (USAID). A small number of global non-governmental organisations (NGOs) - generalists such as Oxfam, and microfinance-focused ones such as ACCION International, Opportunity International, and Grameen Foundation - play important roles as rule-making MFI umbrella organisations and funders.

3. National regulators - the global database Microfinance Information Exchange (MIX) registers MFIs in 115 different countries. While most governments have not created dedicated regulations for microfinance, almost everywhere MFIs fall under some legal frameworks, including prudential regulation or the laws governing non-profit entities; this makes national regulators potentially important actors.

4. MFIs are on the rule-implementing side. They can generally formulate and implement their own day-to-day procedures, but are subject to frameworks and rules designed and relayed down from funders, international organisations, and regulators. Importantly, these include frameworks defining the expected rates of loan repayment, as well as standards for financial reporting and social reporting. MFIs range from small, local, semi-professional NGO-type operations to some large cooperative programmes, as well as major commercial MFIs with millions of borrowers. The sector is diverse, but the market 
is nonetheless concentrated: the 15 largest MFIs all have loan portfolios of over one billion US dollars, and many countries are dominated by just one or very few large commercial MFIs. ${ }^{3}$ Some commercial banks which serve poor clients in addition to their usual clientele also are counted as MFIs. Managers, professional staff and loan staff are key implementing agents in this actor group.

5. Clients - on the rule-receiving end, the highly diverse clients, roughly 200 million, are traditionally viewed as small businesspeople but, more often than not, they are also (or instead) subsistence farmers, casual labourers, low-income employees, or housewives. Even at the very local level, clients are heterogeneous, and borrower groups often reflect local power structures and hierarchies. Three quarters of borrowers are women (Reed, 2014), however in many cases husbands or male relatives use their loans (cf. Rahman, 1999).

6. Social movements - insofar as they can be seen as actors, two sets of movements are of particular interest. First, a global 'microfinance movement' of aficionados has crystallised around the industry; it includes over 1 million private individuals in the global North who use the on-line lending platform Kiva to make socially-conscious microloans that seek to help poor people through 'entrepreneurial philanthropy' (Bajde, 2013). Second, a number of borrowers' movements have emerged spontaneously in the global South to voice grievances and discontent, for instance the No Pago and Victimes $d u$ Microcredit protest groups in Nicaragua and Morocco.

\section{Concepts}

Halliday and Carruthers (2007, p. 1142) highlight that legal concepts have a 'constitutive power' in framing the way the subjects of law come to view their problems. This draws our attention to how rule-making processes constitute a 'terrain of conceptual struggle' (Halliday and Carruthers 2007, p. 1193) or diagnostic struggles (Halliday and Schaffer 2015), in which different actors promote and contest different ways of framing issues and seeking solutions. In microfinance, different conceptions of what the goals and desirable behaviours of microlenders should be have shaped the sector over time. Key concepts, discussed in further detail below, include 'sustainability', which is understood primarily as a financial goal - MFls should self-sustain through being profitable - and 'outreach', which refers to reaching a maximum number of poor clients. Both concepts served to facilitate market-building, by painting MFIs as growth-oriented businesses. Likewise, newer conceptualisations of 'social performance' and 'responsibility' reflect growing donor concerns for reporting and monitoring of social impacts, and have also shaped microfinance practices.

\section{Institutions}

The bodies which disburse microloans and other microfinancial services are known 'microfinance institutions', but in fact they are organisations rather than institutions in the sociological sense. In keeping with Halliday and Carruthers' meaning of institutions, some important regulatory institutions which have the power to develop and enforce rules for MFIs can be identified. Although there is not much formal or fiat authority in microfinance (except for government regulation to different extents, depending on the country), institutional authority exists. Above all others, the World Bank, as well as a small number of internationally-active NGOs and investor networks, has worked successfully to institutionalise more-or-less binding rules for MFIs. They are not legally-binding, but they work de facto as commonsense or practically unchallengeable regimes. The World Bank and these NGOs attained their central status as rulemaking institutions by controlling MFIs' access to funds, both directly through providing or channelling capital, and indirectly through signalling to other funders the financial and social credibility of particular MFIs.

\section{Form of rules}

Halliday and Carruthers (2007, p. 1143) finally highlight how recursivity analyses (of law) must be 'attentive to the influence of the form of law itself - regulations, cases, codes - on the way change is implemented or initiated'. The formal laws of sovereign states play a framing role for MFls and their investors. But the rules which shape microfinance are often more transnational in scope and more closely resemble instruments of soft law. They include optional rating and evaluation schemes, best practice guidelines, collective mission statements and corporate principles, explicit and implicit conditionalities attached to funds and shared informal normative templates. Despite being 'soft' frameworks, due to being propagated or supported by key institutions in the field they nonetheless exert strong regulatory force, in particular when they determine MFIs' ability to access funds. Nationally-developed or network-specific codes of conduct and standards play a role, but these tend to reflect transnational industrywide frameworks and the demands of globally-active funders.

To sum up, microfinance is a field populated by heterogeneous actors, including funders, international organisations and national regulators as rule-makers; MFIs as rule-implementers; clients as rule-receivers; and social movements that have received but also sought to shape rules. Concepts matter in that different conceptions of the aims and means of microfinance have pushed MFls toward 'sustainably' pursuing 'outreach', and more recently also toward 'social performance' and 'responsibility'. Key institutions are the World Bank and a few large NGOs and investor networks, who hold the power to make rules. While many or most of the important rules in microfinance are formally voluntary, they nonetheless exert strong regulatory force.

\section{Open and restricted channels of feedback}

Through professionalisation and commercialisation, microfinance evolved from a field of small, dispersed local NGOs into an integrated and distinct financial sub-sector containing both commercial MFIs and large professionalised NGO- 
MFIs, both pursuing commercial methodologies. The 'diagnostic struggles' (Halliday and Schaffer 2015) over the means and ends of microfinance, and the governance processes through which they found expression in this evolution, will be examined here in three subsections: (I) the global standardisation of microfinance following a financial template; (II) the creation of standards and systems for social performance management; and (III) the search for systems to build 'responsible' microfinance. This analytical history exposes the opening as well as restriction of different channels of upward feedback.

\section{Scaling-up and financial standardisation (I)}

Microfinance has a long and rather opaque pre-history, beginning with European colonial social policy, which informed an array of civil society and state-led credit initiatives after independence; for a more extensive history, see Mader (2015). Microfinance 'proper' - small loans given by non-government agencies - emerged into the development mainstream in the 1980s, when the Third World debt crisis and the neoliberal turn in development truncated the economic role of southern governments, and the practice by some NGOs of making small loans was seen to fit well with neoliberal ideas of development as a private sector-driven process. The self-sustaining small-loan projects of some NGOs, collected under the label 'micro credit', caught donors' attention, in particular thanks to their high repayment rates. In spite of initial concerns about it being too grassroots and small-scale, the World Bank adopted microcredit in the mid-1980s and integrated it with Structural Adjustment Programmes, to foster self-employment and market development. When it and other early supporters (such as USAID) adopted microfinance, they began to work to enhance NGOs' capacity to attract private funds, in order to eventually cut them loose (Bateman 2010; Weber, 2002).

Key concepts guiding this commercialisation process were 'outreach' - MFIs should grow to reach as many poor people as possible - and 'sustainability' - MFIs should be able to self-finance and grow without further donor money. The push for outreach and sustainability entailed in many cases transforming NGOs into formal financial institutions, or at least 'no-frills' professional lenders. ${ }^{4}$ After initially mainly acting as an advisor, the World Bank also began to directly fund MFIs, primarily through its International Finance Corporation (IFC) arm, which facilitates private investments and pursues commercial or near-commercial rates of return. Locating microfinance with the IFC strongly affected what type of organization could gain access to Bank funds, namely those that were willing and able to become 'sustainable' and generate profits satisfactory to mainstream investors.

To further aid the transmutation of NGOs into for-profit, credit-focused entities, the World Bank founded the specialised agency CGAP in 1995. Being intimately connected to the Bank, CGAP soon became a focal point for the nascent microfinance sector. Its focus lay far less on funding MFls than on reshaping the sector as a whole through governance and rule-making initiatives, promoted via strategic 'knowledge management'. CGAP promulgated commercial strategies through its authoritative publications, beginning with a highly influential 'Pink Book' (Micro and Small Enterprise Finance: Guiding Principles for Selecting and Supporting Intermediaries) and continuing with successive 'Consensus Guidelines' that spelled out how different aspects of microfinance ought to work. Regardless of whether these 'Consensus Guidelines' were mere formulations of existing consensuses in the sector (as CGAP would argue), or rather were building blocks of a more coercive 'Washington Consensus on poverty' (Roy 2010, p. 47) imposed by CGAP and others, they were milestones in the sector's evolution. With clearly-formulated rules, they formalised the process for standardising MFIs as entities that should focus on communicating financial results rather than, for instance, social impacts. As Table 1 shows, CGAP's rules were focused on reshaping microfinance as a commercial sector, and only after firmly establishing the commercial approach did concerns for adequate regulation and monitoring social metrics enter, never taking centre stage. An examination of the famous 1995 'Pink Book' ${ }^{\prime 5}$ and its (also pink-bound) 2004 sequel reveals the influence CGAP sought and attained in governing the microfinance field.

The 1995 book tersely articulated strategies that donors should pursue, above all for fostering MFIs' commercial outlook and investability. All donors must follow the same principles, the 'Pink Book' stipulated, and not undermine individual MFIs' incentives to 'become financially viable' (World Bank, 1995, p. x). Of the 12 performance standards it articulated, the only one making any reference to clients was MFIs should show 'a distinct commitment to reaching the poor' (World Bank, 1995, p. vii) - notably not alleviating poverty - while the other 11 indicators pertained to institutional governance, growth, and financial performance. Of the 44 'minimum reporting information' elements it listed, only two (percentage of female clients and effective annual interest rate) remotely pertained to clients' experience of microfinance (World Bank, 1995, pp. xii-xiv). According to the 'Pink Book', MFIs above all should be efficient, financially transparent organisations, and work to reduce their dependence on subsidies (World Bank 1995, pp. vii-viii).

The more extensive and detailed 2004 'Donor Guidelines' struck an even more authoritative tone (verging on triumphant) as CGAP could point to its eleven 'Key Principles of Microfinance' having been endorsed by the G8. Many NGOs had already transformed into financially streamlined MFIs, or were doing so, so CGAP was free to address new audiences. It redefined its mission from building MFIs to 'building financial systems that serve the poor', and instructed donors to exert greater pressure on governments to remove interest rate ceilings and curb government lending, so as to make space for the growth of private MFIs as the keystone of financial systems for the poor. CGAP also criticised some donors for still coddling MFIs with subsidies, thereby 'distorting markets and displacing local commercial initiative with cheap or free money' (CGAP, 2004, p. 6). Although the 2004 Guidelines also for the first time mentioned social performance, they clarified that, unlike for 
Table 1. Notable 'consensus' publications

CGAP publication title

1995: Micro and Small Enterprise Finance: Guiding Principles for Selecting and Supporting Intermediaries ('Pink Book')

2003: Microfinance Consensus Guidelines: Definitions of Selected Financial Terms, Ratios and Adjustments for Microfinance

2003: Microfinance Consensus Guidelines: Guiding Principles on Regulation and Supervision of Microfinance

2004: Building Inclusive Financial Systems: Donor Guidelines on Good Practice in Microfinance

2010: Microfinance Investment Vehicles Disclosure Guidelines: Consensus Guidelines

2012: A Guide to Regulation and Supervision of Microfinance: Consensus Guidelines
Key new ideas promoted in this publication

- donors should select and support MFls oriented towards growth and financial results;

- financial sustainability is the means for expanding and maintaining outreach;

- financial information is the minimum information which donors should require from MFls (defined in Annex).

(update \& expansion of 1995 'Pink Book' Annex)

- standardised methods for calculating financial ratios to enhance transparency vis-à-vis donors and investors

- large parts of microfinance activity should be exempt from prudential regulation (pertaining to system stability);

- microfinance requires simpler rules than other finance;

- MFIs should be formal but separate, less-regulated actors;

- interest rate caps/limits should be avoided (in part because they draw attention to MFIs' high rates).

(revision \& expansion of the 'Pink Book')

- donor support for microfinance should be about building financial systems, not individual MFIs;

- donors should entice (never replace) private funding;

- government has no business offering financial services;

- regulators should liberalise the financial sector;

- social performance is an emerging issue (but no consensus on measurement).

- a transparent market for microfinance investment opportunities means MIVs should standardise how they report to investors;

- social performance should be reported (using readily available indicators; not measuring impact).

(revision, update \& expansion of 2003 guidelines)

- regulators should aim for 'full financial inclusion';

- special regulatory windows needed for microsavings;

- selective regulation for consumer protection is acceptable (interest rate transparency, preventing predatory lending, preventing abuse of credit life insurance).

Source: Own work, drawing on CGAP (2003a, 2003b, 2004, 2010, 2012) and World Bank (1995).

financial performance, no consensus existed on how to monitor social performance. In short, the 2004 Guidelines strengthened and the sector's commercial orientation with clearly-formulated market-oriented rules for a variety of stakeholders to follow.

As a governance institution created by the World Bank, and associated with the Bank's power in the development space, CGAP worked to reconfigure MFIs into streamlined communicators of financial information; that is, to speak with Hirschman, information channels focused on monitoring client 'exit' (borrowing and repayment). CGAP's success as a governance institution came from a combination of the three types of influence which Halliday and Carruthers (2007) suggest advance the adoption of voluntary rules: (1) economically coercive pressure, (2) moral persuasion and (3) normative modelling. First, due to its close proximity to the World Bank, currying CGAP's favour was crucial for MFIs seeking capital. Second, far from only appealing to MFIs' profit motive, CGAP's commercial standards were underwritten with moral suasion as they promised that financially successful MFIs would reach the most people; conversely, they depicted non-commercial, subsidy-dependent operations as inefficient and harmful. Third, normatively speaking, fastgrowing commercial MFIs (and commercially-streamlined NGOs) came to be seen within the sector as successful and dynamic examples, while non-profit, grassroots ideals were staid and old-fashioned. CGAP's work thus shaped the 'Washington consensus on poverty' which other microfinance stakeholders adapted to or were urged or forced to adopt (Roy 2010). ${ }^{6}$ As noted in an internal assessment, CGAP 'played a pivotal role in developing a common language for the industry, catalysing the move towards best-practice performance standards, and building a consensus among varied stakeholders' (Bhatnagar et al. 2003, p. 4). 
The changes wrought by CGAP enjoyed broader support and were also espoused by other influential organisations, notably USAID, other Washington-based institutions, and large international NGOs (Roy, 2010). In 1997, for instance, ACCION, an early NGO sponsor of microcredit in Latin America and later a major investor, published its own 'best-selling $^{\prime 7}$ manual on financial management for MFls, which stipulated that MFIs should focus on monitoring 'the financial criteria and techniques that may be most helpful to managers who want to improve their institutions' performance' (Christen, 1997, p. 10). ACCION highlighted 'four key challenges' faced by MFIs, all distinctly financial challenges: insufficient levels of loan repayment; insufficient cost recovery; failure to access commercial funding; and failure to attract for-profit equity investors (Christen, 1997, p. 15).

Thus, the microfinance industry's governance in the era of scaling up and financial standardisation, from the 1980s until roughly the mid-2000s, was formalised and formulated in clear rules with quasi-coercive power over MFls. While focusing on streamlining the financial channel, they envisioned little agency for clients beyond the binary of exit borrowing and repaying. The rules, normative templates and diagnostic instruments of financial standardisation deployed by key institutions wrought microfinance from an NGO sector into a transnational market in which potential investors and creditors could seek MFIs to invest in, based on what these MFIs communicated about their clients' desire to pay for microfinancial services. Beyond voting with their feet (or wallets), clients gained no participation or voice in shaping microfinance.

\section{Social performance management (II)}

As commercialisation went forward in the 1990s and 2000s, microfinance also rose to wider fame, most notably with the 2006 Nobel Prize for Peace awarded to Muhammad Yunus and Grameen Bank. The 2000s, however, were also a time during which serious questions about the beneficent impacts of microfinance were raised by many researchers ${ }^{8}$, and some wholesale critiques were launched against the concept (most pointedly Bateman, 2010). A series of prominent MFI privatisations and profitable stock market flotations went forth in the late 2000s, raising the question of whether commercialisation had led to harmful 'mission drift', as commercial goals and practices - larger loans, larger profit margins - superseded social goals in many MFIs (Mersland and Strøm, 2010).

Efforts to ensure MFIs' social performance in the commercial microfinance led to the creation of a 'Social Performance Task Force' (SPTF), the origins of which reach back to a 2005 meeting co-organised by CGAP. The SPTF brought together many important organisations and became the centrepiece of global sectoral governance activities for performance beyond the financial bottom-line ${ }^{9}$. It claims to have 'over 2,600 members from all over the world and every microfinance stakeholder group' (SPTF, 2015) - except, one may note, the clients. Although social performance management might suggest a focus on assuring effective social performance, instead only standards for how MFls might report on their pursuit of social performance were defined. The SPTF never created or defined absolute measures for MFIs' social impact. Instead, the SPTF defines social performance as 'the effective translation of a microfinance organization's mission into practice' (SPTF, 2015). Its 'Universal Standards for Social Performance Management':

do not dictate what specific social goals an institution should have, but identify the management practices that help an institution make progress toward its chosen goals [ ... ] a significant, voluntary effort by the microfinance sector to self-regulate. [ ... ] This enhances the credibility of our institutions and the reputation of our industry' (SPTF, 2012).

This passage clarifies that, when committing to the SPTF, MFIs remain free to choose how much social performance they aim for. Its concept of social performance is voluntary and managerial.

MFIs can choose among several audit tools and systems for reporting on how they manage their social performance, among which the 'CERISE SPI4' tool has come to considered as leading; it is most strongly endorsed by the SPTF. According to CERISE's promoters, by end of 2015, more than 120 CERISE-based audits worldwide had been completed or were under way (CERISE 2015). These audits are voluntary, intended for internal use only, and their results are rarely published. The SPI4 tool ${ }^{10}$ calculates percentage scores for MFIs, based on their responses to a 253-indicator questionnaire reflecting the six dimensions of the SPTF's 'Universal Standards', which are: (1) define and monitor social goals; (2) commitment to social goals; (3) design products that meet clients' needs; (4) treat clients responsibly; (5) treat employees responsibly; and (6) balance social and financial performance.

Examining how the SPI4 tool works in practice, it becomes clear that it abstracts the question of impact away from MFIs' actual performance towards clients, and redefines it as a question of organisational formal structure. Scores on each SPTF dimension reflect MFIs' bureaucratic arrangements rather than their ground-level impacts, and only very few SPI4 indicators even involve collecting information generated by or pertaining to the clients, even indirectly. One rare exception is 'The complaints mechanism is actively used by clients (yes/partially/no)' (Indicator 4 e 3 5), where at least client engagement appears to matter.

Particularly interesting is how the SPI4 tool formalises the way MFIs monitor clients' poverty. Under dimension 1 (define and monitor social goals), the indicator for poverty targeting of new clients is: 'The institution systematically collects data to measure poverty outreach to new clients', which prompts a 'yes/no' answer. Clearly, what matters is that an organisation collect such data, not what the data show (i.e. whether clients are poor, or not). Likewise, the indicator 'The institution monitors the progress of the poverty status of its clients over time' is assessed using three binary questions: 
Detail 1 b 521 The institution uses a systematic approach to track progress of poor clients. (yes/no)

Detail 1 b 522 Analysis accounts for drop-outs affecting the results. (yes/no)

Detail 1 b 523 Data quality for tracking progress is of robust quality (yes/no)

Never is it asked whether clients' poverty status actually improves; MFIs only are asked to report whether they monitor baseline poverty, or not. Meanwhile, many other indicators are of even more questionable relevance for social performance, as with whether or not the institution's Code of Conduct has been reviewed and approved by the board (Indicator 2 b 2 2), or whether the MFI offers bonuses to loan officers for reducing overdue loans (Indicator 2 c 4 5). How such aspects should enhance MFIs' social impact or performance from a client perspective remains nebulous.

Other, somewhat less prominent, social performance management tools exist, such as the Progress out of Poverty Index (PPI), developed and trademarked by the Grameen Foundation. For the PPI, MFIs periodically sample clients and ask them ten questions to reflect their statistical likelihood of living under the poverty line. While this is clearly more empirical than the SPI4 approach, nonetheless questions remains around how well the PPI (which only establishes a 10-question proxy indicator) manages to capture client poverty, let alone whether any improvements found actually reflect the impact of microfinance, or instead are exogenously driven, as no 'control' populations are monitored. Like the SPTF, PPI results also remain private and shrouded in a veil of secrecy, as they are not published. The most recent Global Report on Poverty Measurement with the Progress out of Poverty Index (Grameen Foundation 2014) does not report impacts; it only reports which organisations use the tool.

By offering clients no scope for voice or participation, as a channel for recursive rule-revision social performance management is clearly restricted, showing how the form of rules matters. By comparison with CGAP's very rigid and welldeveloped rulebook for ensuring MFIs' financial sustainability, and the obvious financial punishments underperforming MFIs face - including donor sanctions and investor pressure - social performance management exerts only very weak normative and practical force. There is no evidence even that non-audited or socially poorly-performing MFIs face problems attracting funds, or that failing an audit bears any reputational risk (results are not published). Most troublingly, social performance management involves hardly any collection or transmission of information from clients, and instead merely evaluates MFIs' formal processes. As even a publication for the (CGAP-founded) Microfinance Information Exchange (MIX) notes: 'Indian MFIs, like their peers in other countries, still have difficulty reporting outcomes related to their social goals, a sign that MFI social performance management practices remain focused on procedures rather than outcomes' (Foelster et al., 2014, p. 1, emphasis added).
Social performance monitoring, as currently conceived, thus neither conveys meaningful feedback passively information about incomes, empowerment, asset accumulation, or satisfaction, which broader publics and clients themselves are likely to associate with 'social performance' - nor gives clients a voice in microfinance actively. Instead, it may even serve to insulate MFls and their funders against client feedback and critiques, by simulating concern for monitoring social impacts. As the SPI4 indicators show, what is assessed is MFIs' efficacy at the art of performing socially for funders, rather than their social performance towards clients. This channel of recursivity is clearly restricted.

\section{Crises and the discovery of responsibility (III)}

A number of countries have experienced severe microfinance crises, caused by saturation and overlending, including Bolivia in 2000, in Bosnia-Herzegovina, Nicaragua, Morocco and Pakistan all in 2007-2008. India experienced major crisis events in 2005,2009 , and most devastatingly in 2010 , when protests, violence, and between 50 and 88 suicides within one month forced a shutdown of MFIs' operations in Andhra Pradesh (Mader 2013). Notwithstanding different details and local factors, there were key commonalities in all crises: they occurred in well-developed markets (not backwaters) dominated by professionally-run and commercially-successful MFIs; they were preceded by a marked acceleration of lending (see Figure 2); MFIs had attracted much commercial investment (cf. Arunachalam, 2011); and MFIs competed heavily against each other and against other lenders, making larger loans and feeding distressed borrowers further debt (see Mader 2015). In all cases, widespread over-indebtedness built up until a sudden event triggered mass loan defaults, often accompanied by borrowers protesting and media reporting negatively on MFIs for charging excessive interest rates and abusing clients (Guérin et al. 2015).

These microfinance crises may be seen as instances of clients collectively exercising voice and practicing exit; that is, expressing dissatisfaction through protest, violence, seeking political support against MFIs, and not repaying. They demonstrated to sector leaders that client discontent could threaten entire national sectors and harm the industry's global reputation. A key response since then has been to propagate standards for 'responsible microfinance', as a new guiding concept for the sector.

The September 2012 'Global Appeal for Responsible Microfinance', signed by some of the largest transnational NGO-type funder organisations, formally launched 'responsibility' into the public domain. Unsurprisingly, it reiterated the signatories' position that donors and the general public should still support microfinance. But it also noted that '[w]hen institutions adopt overly aggressive development policies, charge excessive interest rates, and implement abusive recovery policies, they discredit the very model of microfinance and could harm vulnerable borrowers' (Convergences 2015, 2012). The term 'responsibility', practically unheard before 2010, has crystallised as the key concept 
underlying a new set of governance initiatives in microfinance. While some institutional and conceptual overlaps with social performance exist, 'responsible microfinance' remains distinct, in that social performance aims for MFIs to better demonstrate their beneficence, while 'responsible microfinance' acknowledges the possibility of too much, or the wrong type, of microfinance activity.

Two leading initiatives that have emerged around 'responsibility' are the 'Smart Campaign' (mainly promoted by NGO-investor network ACCION) and the Truelift 'Pro-Poor Seal of Excellence' (less prominent, but also supported by actors from throughout the sector, including commercial investors ${ }^{11}$ ). The Smart Campaign has become the most visible and influential 'responsibility' initiative; its certification attests that an MFI takes 'adequate standards of care' in implementing seven 'core Client Protection Principles'. ${ }^{12}$ Certification follows upon a desk review and a 4-6 day site visit by auditors, involving staff interviews and client focus groups (Smart Campaign 2014). ${ }^{13}$

Smart boldly proclaims that its principles are akin to a 'Fair Trade standard in microfinance', but in the fine print cautions that 'Adequate standards of care [ ... ] don't serve as a guarantee of every individual or institution's behavior. The standards are simultaneously meant to be achievable for most financial institutions with the desire to meet them' (Smart Campaign 2013a; 2014). MFIs can indefinitely re-apply for Smart certification, and (as with SPI4 audits) any failures to be certified are kept private (Smart Campaign 2014). Truelift follows a more unsystematic and ultimately similar approach of voluntary assessment based on three vague principles: focus on poor people, adequate services, and tracking of clients' progress (Truelift, n.d.).

Even though these initiatives reveal 'responsibility' standards to be softer and less enforceable than financial standards, they may nonetheless encourage some meaningful feedback from clients. After all, Client Protection Principle 7 stipulates that MFIs must have timely and responsive mechanisms for complaints resolution; this clearly proposes a channel for client perspectives to feed into microfinance practices. Smart specifies: 'The [financial institution's] clients are aware of how to submit complaints', 'The Fl's staff is trained to handle complaints', 'The Fl's complaints resolution system is active and effective', and 'The $\mathrm{Fl}$ uses client feedback to improve practices and products' (Smart Campaign, 2013b). However, it remains unclear to what extent and how MFIs actually use the client feedback - to redesign services and approaches, or merely to address individual aberrations, such as dismiss a particularly abusive loan officer. It also remains unclear whether feedback percolates upward beyond MFIs to the rule-makers in microfinance (funders, international organisations, or regulators).

What further risks restricting the 'responsibility' channel is the fact that CGAP, otherwise a prolific and potent setter of international standards, has remained aloof. CGAP did not sign the Global Appeal (unlike 500 other organizations and 1,500 individuals $^{14}$ ) and its position paper on responsible microfinance highlights:
Industry self-regulation needs to be at the core [ ... and] lower income households at the base of the pyramid need to do their part for responsible finance by developing the skills, knowledge, and attitudes that help them "self-protect" and better navigate financial decision making. (McKee et al., 2011, p. 3)

Thus, instead of encouraging binding responsibility arrangements, CGAP suggests clients should learn to 'self-protect'. Moreover, its most recent five-year-plan emphasises it already 'played an important role in promoting responsible finance, especially consumer protection' (CGAP, 2013, p. 20), and its future objective is to foster 'responsible market development' (CGAP, 2013, p. 21). The term is never clearly defined, but indicates the priority placed on market development rather than regulation or restraint.

Another reason to doubt that serious changes will arise from commitments to 'responsibility' is the inaction of MFIs and funders on a fundamental issue for clients: the price of credit. The Smart Campaign's principles remain highly unclear and presumably deliberately permissive on the question of pricing (Client Protection Principle 4). Smart only specifies: 'The $\mathrm{Fl}$ offers market-based, non-discriminatory pricing'; 'The Fl's efficiency is in line with its peers'; 'The FI does not charge excessive fees' (Smart Campaign, 2013b) notions which are open to flexible interpretations. Mexico's Compartamos Banco, notorious for charging nearly 200 percent compounded annual interest (Roodman, 2011), obtained Smart certification in August 2014.

Sector-wide commitments to transparency (Principle 3) are similarly doubtful. The industry-wide interest rate watchdog MicroFinance Transparency was forced to announce its closure in March 2015, with CEO Chuck Waterfield explaining in his final message that:

whether operating alone or operating through or with other partners, we ran into the same challenge: MFIs are either reluctant to become vulnerable by voluntarily sharing their pricing data (the majority of the industry), or they are simply unwilling to do so (a small portion of the industry) (Waterfield, 2015).

Again, the form of rules matters profoundly. The reluctance of industry bodies such as CGAP or ACCION to regulate, standardise or even just monitor the price of credit (and MFIs to facilitate) suggests that 'responsibility' is weak and restricted as a potential feedback channel. On interest rates and repayment burdens, which were central to clients' grievances expressed in the microfinance crises, there is no attempt to grant clients any voice or input. Instead, responsible pricing is defined via vague formulations and comparisons with MFIs' peers.

In 2014, Smart launched the Client Voice project, a research (not practice) initiative led by financial inclusion advocates and industry consultants. Its recently published results are striking but contradictory. The synthesis report of four country studies keenly points out '[o]verall, we 
Figure 2. Growth and crisis of several national microfinance sectors

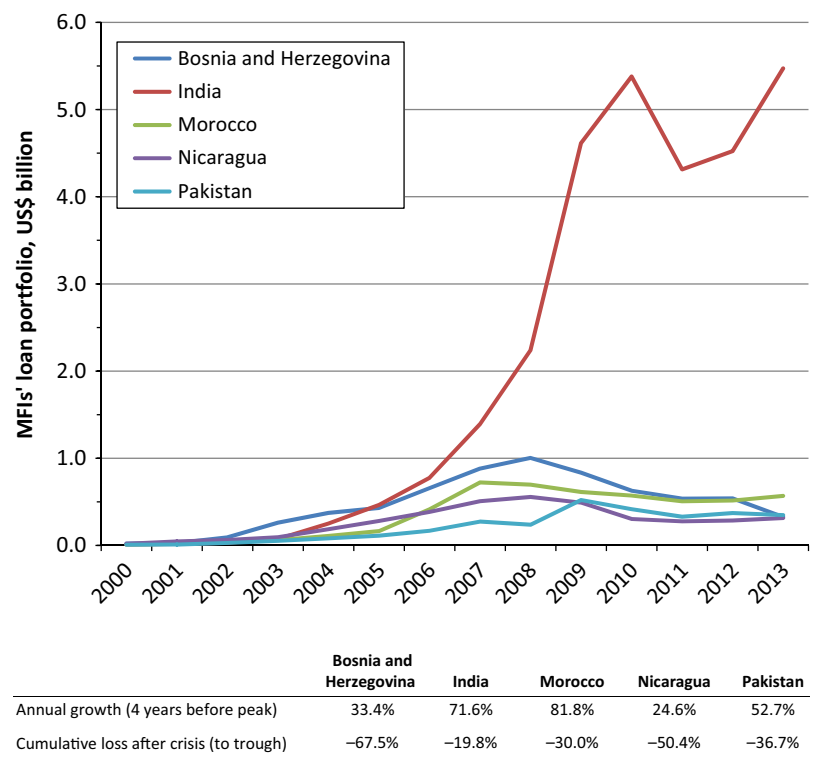

Note: Bolivia is not shown due to lack of pre-crisis (2000) data Source: MIX data (www.themix.org), downloaded 3 August 2015.

discovered that [ ... ] clients are generally satisfied with MFIs (Microfinance critics, take heed.)' (Meka and Sanford 2016, p. 4). However, clients quoted throughout the report voice deep mistrust, suspicions of being tricked, and feelings of being exploited. They report often sacrificing essentials or going deeper into debt to repay loans (Meka and Sanford 2016). The report's conclusions emphasise that more transparency is needed in practice (communicating terms so that clients understand them), being more flexible and empathetic towards those who encounter problems, and making complaints mechanisms more accessible (Meka and Sanford 2016). But they do not suggest including clients' voice beyond the scope of the Client Voice project, which appears to have ended (Meka and Sanford 2016).

Because 'responsibility' initiatives in microfinance are still taking shape, firm conclusions about their ability to transmit feedback may be premature. However, as seen here, there are reasons to doubt 'responsibility' (as presently defined) makes the sector substantially more reflexive or responsive to clients. Other potential routes of recursivity and feedback may of course be opened in future, or 'responsibility' be strengthened over time to become more meaningful. Fragments of such a model could be found in Grameen Bank, which allows selected borrowers to hold seats on its board, and its borrowers to own shares. But Grameen is hardly representative for the wider sector, and moreover, critical experts argue its borrower inclusion in governance is mere window-dressing. Karim (2010: xxiii) reports that Grameen clients are mostly unaware of their apparent powers, and shareholder dividends have rarely been paid out to clients.

So far, the practices resulting from the concept of 'responsible microfinance' - adapting product design and marketing, monitoring over-indebtedness, improving transparency (or claiming to do so), and 'responsible pricing' - look more geared towards strengthening mechanisms of exit rather than voice. They invite clients to take better-informed decisions, but not to shape what is offered. Even if 'responsibility' initiatives see the sector becoming more 'responsible' on its own terms, these initiatives have granted at best a narrow, restricted, form of voice to borrowers. Designing systems for meaningful client voice and participation in microfinance remains challenging as it runs counter to the financial logics of the sector.

\section{Conclusions}

The concept of recursivity denotes possible reciprocal interactions between regulators and regulatees, or more broadly, between the making of rules and their implementation, when feedback triggers their revision. Participation means that the subjects of development should shape the interventions directed at them. As pertains to development, these notions are clearly connected, in that both recursivity and participation require giving voice to the subjects of development regarding the rules which govern the interventions directed at them.

As seen here, microfinance has problems with being recursive and participatory. In microfinance, one feedback channel consistently takes precedence over others: the financial channel, which communicates borrowers' entry or exit. Particularly with microfinance being a cornerstone of broader campaigns for global 'financial inclusion' (Mader 2016), the question of how to meaningfully include borrowers' voice in financial development interventions should gain salience. However, as practised to date, modes of participation and inclusion of client feedback in microfinance are restricted to technocratic-managerialist approaches and vague, non-committal promises.

The two supplementary channels of feedback built into microfinance in recent years - 'social performance management' and 'responsible microfinance' - remain severely restricted in their capacity to relay feedback from borrowers to rule-makers. Social performance management was developed to respond to criticisms and doubts about microfinance positively impacting borrowers, but crystallised as a technocratic and managerialist exercise for assessing the MFI's internal systems, rather than the social impact on borrowers. Neither are clients' income, empowerment, asset accumulation, or satisfaction meaningfully assessed and reported, nor clients granted direct voice or input on microfinance rules. Meanwhile, 'responsible microfinance' efforts have followed upon a succession of crises that exposed deep borrower discontent, but they too remain severely restricted as channels of feedback. To the extent that borrowers' grievances are assessed and understood via responsibility initiatives, this information is likely to be absorbed 
into MFls rather than communicated further; enforcement mechanisms remain very weak; and the commitment of many actors to principles of responsibility beyond rhetoric is doubtful.

Is the 'restricted' form of recursivity then really a form of recursivity at all, given that the voice of rule-subjects is not meaningfully fed back to the rule-setters (international organisations, funders, national regulators)? The phenomenon here is that feedback systems are put in place, probably even with the genuine intention of empowering clients, yet by their design, the systems are dysfunctional, at least in terms of including borrowers' voice and relaying it up the microfinance value chain into re-shaping the rules. 'Restricted' recursivity thus is where channels for upward feedback are formally opened, but their capacity to communicate meaningful feedback which could generate changes in rules remains restricted. In the case of microfinance, this is because financial channels always take precedence and squeeze other potential channels of voice and feedback.

These insights underscore the promise of further expanding the view of recursivity studies, which have often focused on states and professional actors within legal systems (e.g. Halliday and Carruthers 2007; Halliday and Shaffer 2015), to examine different modalities of participation and non-participation for grassroots subjects and recipients of rules. As seen here, not only MFIs but also their borrowers are ruled, yet present arrangements grant them little or no voice. With the selective restrictions seen in microfinance, it becomes clear that the relative priorities granted to different feedback channels in a governance system matter, and that participatory feedback cannot easily be designed into a system as an add-on; at least not without questioning the way the system operates. Particularly given manifest efforts to articulate channels for upward feedback, which have not succeeded, a deeper understanding of what leads to feedback being restricted, or even more benignly, just getting 'lost in translation', may be gained through analogous studies of other governance systems.

One conclusion from examining microfinance, then, is that feedback channels which contradict dominant conceptual frames in a particular governance field - here: outreach and sustainability (or growth and profitability) - are liable to allow only very restricted forms of feedback. Organisations like MFls, faced with contradictory aims, can be expected to prioritise what ensures their immediate survival; and in a system dominated by commercial entities and logics, this is clients' entry or exit (to borrow and repay, or not), instead of clients' voice regarding what services or conditions would benefit them more. With potential harm to borrowers being a real concern, independent watchdogs and grassroots associations to represent debtor interests would appear to hold more promise for giving clients voice than proceeding further with industry self-regulation. Donors might also want to shift their focus towards supporting indigenous grassroots financing initiatives (like cooperatives) which could constitute credible alternatives and competitors to MFIs, forcing MFIs to act more responsively and accountably.
A notable feature in the case, of course, was the series of crises in which borrowers collectively resorted to external channels for giving feedback and exerting pressure, including mass protests, violence, and appeals to political elites and the media. The voice which borrowers have exercised so far has usually come through such sporadic, outbursttype episodes of discontent, which have sometimes been picked up and channelled by governments into piecemeal or hasty regulation. A second conclusion, then, is that where internal processes fail to give meaningful voice to rule-subjects, outbreaks and regulatory reactions may be necessary, even desirable, correctives. They could also themselves be seen as processes of recursivity, albeit ones which are external to the governance system itself, playing out in the broader socio-political space.

\section{Notes}

The author wishes to thank Olga Malets, Sigrid Quack, Jonathan Zeitlin, two anonymous reviewers, and the participants of a workshop at the Society for the Advancement of Socio-Economics (SASE) Conference in London, for highly valued input on earlier versions. Responsibility for all errors is, of course, the author's own.

1. 73.2 per cent of loan portfolio was held by MFIs reporting to the MIX as for-profits; calculated using MIX Cross-Market analysis data for 2012, downloaded 10 August 2015.

2. Loan figures: www.mixmarket.org, last accessed: 10 August 2015. Clients: Reed (2014, p. 8).

3. As per data reported to the MIX for the year 2012.

4. 'No-frills' means not offering other, less profitable services beyond credit, such as savings or business advisory services.

5. It was not yet officially published by CGAP, but by the committee from which CGAP emerged.

6. Roy (2010, pp. 45, 93ff.) highlights this consensus was around 'a market-based approach to poverty' as opposed to an earlier NGOdriven 'Bangladesh Consensus'.

7. 'Best-selling', as ACCION claims. Available from: http://www.centerf orfinancialinclusion.org/publications-a-resources/browse-publica tions/84 [accessed 26 August 2015].

8. Some widely-noted studies in the 1990 s concluded that access to microcredit reduced poverty. But their methodology was upwardbiased, and other contemporary studies proved less sanguine. Later, randomised studies conducted in the late 2000s were unable to show significant effects on income growth, asset growth or empowerment; see summary in Mader (2015, p. 8-17).

9. Countless smaller monitoring and evaluation initiatives were also launched, some even with explicitly participatory aims (cf. Burke 2015). But these were driven mostly by individual donors and applied to single MFIs or a small set of MFls. In terms of scale, scope and globality nothing rivals the SPTF and the less-widespread PPI (below).

10. Beta version SPI 4 v1.0.1.xlsm. Available from: http://spi4wiki. pbworks.com/w/browse/\#view=ViewFolder\&param=SPI\%20Tool [accessed 27 July 2015].

11. See: https://sealofexcellence.wordpress.com/about-truelift/leade rship-and-team.

12. The seven principles are: appropriate product design and delivery; prevention of over-indebtedness; transparency; responsible pricing; fair and respectful treatment of clients; privacy of client data; mechanisms for complaint resolution (Smart Campaign, n.d.).

13. Where and how the focus groups and interviews are held (e.g. in the MFI office, at people's homes) and how clients and staff are 
sampled (by the MFI or by the certifier) was not disclosed by representatives of the Smart Campaign despite repeated inquiries (personal communication 22 October 2015, 29 February 2016 and 9 March 2016).

14. List of signatories. Available from: http://www.theglobalappeal.org/ signatories/ [accessed 4 August 2015].

\section{References}

Arunachalam, R. (2011) The Journey of Indian Micro-Finance: Lessons for the Future. Chennai: Aapti Publications.

Bajde, D. (2013) 'Marketized' Philanthropy: Mapping Kiva's Utopian Ideology of Entrepreneurial Philanthropy', Marketing Theory, 13 (1), pp. 3-18.

Bateman, M. (2010) Why Doesn't Microfinance Work? London: Zed Books. Beck, S. and Ogden, T. (2007) 'Beware of Bad Microcredit', Harvard Business Review [online], September 2007. Available from: https://hbr. org/2007/09/beware-of-bad-microcredit [Accessed 26 August 2015].

Bhatnagar, D., Dewan, A., Moreno, M. and Kanungo, P. (2003) Empowerment Case Studies: Consultative Group to Assist the Poorest (CGAP) [online]. Available from: http://siteresources.worldba nk.org/INTEMPOWERMENT/Resources/

14872_CGAP-web.pdf. [Accessed 26 August 2015].

Brown, G. (2010) 'When Small is Big: Microcredit and Economic Development', Open Source Business Resource, November 2010. Available from: https://timreview.ca/article/392 [ Accessed 1 August 2017].

Burke, E. (2015) Giving a Voice to the Powerless: Participatory Monitoring \& Evaluation as a Tool for Inclusive Development through Microfinance. Capstone Collection, Paper 2818.

CERISE (2015) SPI4 News - Oct. 2015 [online]. Available from: https:// www.cerise-spi4.org/s/Newsletter-SPI4-Oct-2015.pdf [Accessed 29 February 2016].

CGAP (2003a) Microfinance Consensus Guidelines: Definitions of Selected Financial Terms, Ratios and Adjustments for Microfinance [online]. Available from: https://www.cgap.org/sites/default/files/CGAP-Conse nsus-Guidelines-Definitions-of-Selected-Financial-Terms-Ratios-and-Ad justments-for-Microfinance-Sep-2003.pdf [Accessed 14 October 2015].

CGAP (2003b) Microfinance Consensus Guidelines: Guiding Principles on Regulation and Supervision of Microfinance [online]. Available from: https://www.cgap.org/sites/default/files/CGAP-Consensus-GuidelinesGuiding-Principles-on-Regulation-and-Supervision-of-MicrofinanceJun-2003.pdf [Accessed 14 October 2015].

CGAP (2004) Building Inclusive Financial Systems: Donor Guidelines on Good Practice in Microfinance: Microfinance Consensus Guidelines [online]. Available from: https://www.cgap.org/sites/default/files/ CGAP-Consensus-Guidelines-Good-Practice-Guidelines-for-Funders-ofMicrofinance-Oct-2006.pdf [Accessed 26 August 2015].

CGAP (2010) Microfinance Investment Vehicles Disclosure Guidelines: Consensus Guidelines [online]. Available from: https://www.cgap.org/ sites/default/files/CGAP-Consensus-Guidelines-Microfinance-Investme nt-Vehicle-Disclosure-Guidelines-Sep-2010.pdf [Accessed 14 October 2015].

CGAP (2012) A Guide to Regulation and Supervision of Microfinance: Consensus Guidelines [online]. Available from: http://www.cgap.org/ publications/guide-regulation-and-supervision-microfinance [Accessed 14 October 2015].

CGAP (2013) CGAP Strategic Directions, 2014-2018: Advancing Financial Inclusion to improve the Lives of the Poor [online]. Available from: http://www.cgap.org/sites/default/files/cgap_strategy_20141018.pdf [Accessed 27 August 2015].

Chambers, R. (1994) Paradigm Shifts and the Practice of Participatory Research and Development. Working Paper 2, April 1994. Brighton: Institute of Development Studies.
Chambers, R. (1997) Whose reality counts? putting the first last. London: Intermediate Technology Publications.

Christen, R.P. (1997) Banking Services for the Poor: Managing for Financial Success [online]. Available from: https://centerfor financialinclusionblog.files.wordpress.com/2011/10/banking-services-forthe-poor-managing-for-financial-success.pdf [Accessed 26 August 2015].

Convergences 2015 (2012) 'The Global Appeal', Paris, 19 September 2012 [online]. Available from: http://www.theglobalappeal.org/theappeal [Accessed 27 August 2015].

Dashi, E., Lahaye, E. and Rizvanolli, R. (2013) 'Trends in International Funding for Financial Inclusion'. CGAP Policy Brief, December 2013 [online]. Available from: http://www.microfinancegateway.org/library/ trends-international-funding-financial-inclusion [Accessed 26 August 2015].

Foelster, J., Pierantozzi, A. and Krell, M. (2014) 'State of Social Performance in India: Select Findings', MIX Microfinance World, August 2014 [online]. Available from: http://www.microfinancega teway.org/library/mix-microfinance-world-state-social-performanceindia-select-findings [Accessed 29 February 2016].

Grameen Foundation (2014) Global Report on Poverty Measurement with the Progress out of Poverty Index [online]. Available from: http://www.progressoutofpoverty.org/sites/default/files/PPI\%20Global \%20Report\%202014.pdf [Accessed 22 October 2015].

Guérin, I., Labie, M. and Servet, J. (2015) The Crises of Microcredit. London: Zed Books.

Halliday, T. and Carruthers, B. (2007) 'The Recursivity of Law: Global Norm Making and National Lawmaking in the Globalization of Corporate Insolvency Regimes', American Journal of Sociology, 112 (4), pp. 1135-1202.

Halliday, T. and Shaffer, G. (2015) 'Transnational Legal Orders', in Halliday, T. and Shaffer, G. (eds) Transnational Legal Orders. Cambridge: Cambridge University Press, pp. 3-72.

Heller, P. and Rao, V. (2015) 'Deliberation and Development', in Heller, P. and Rao, V. (eds) Deliberation and Development: Rethinking the Role of Voice and Collective Action in Unequal Societies. Washington, DC: International Bank for Reconstruction and Development / The World Bank, pp. 1-26.

Hirschman, A. (1970) Exit, Voice and Loyalty. Cambridge, MA: Harvard University Press.

Karim, L. (2011) Microfinance and its Discontents: Women in Debt in Bangladesh. Minneapolis, MN: University of Minnesota Press.

Mader, P. (2013) 'Rise and Fall of Microfinance in India: The Andhra Pradesh Crisis in Perspective', Strategic Change, 22 (1-2), pp. 47-66.

Mader, P. (2015) The Political Economy of Microfinance: Financializing Poverty. London: Palgrave Macmillan.

Mader, P. (2016) 'Questioning Three Fundamental Assumptions in Financial Inclusion', IDS Evidence Report 176, February 2016.

McKee, K., Lahaye, E. and Koning, A. (2011) Responsible Finance: Putting Principles to Work. Focus Note, No. 73, September 2011. Washington, DC: CGAP.

Meka, S. and Sanford, C. (2016) My Turn to Speak: Voices of Microfinance Clients in Benin, Pakistan, Peru and Georgia [online]. Available from: http://smartcampaign.org/tools-a-resources/1089 [Accessed 16 March 2016].

Mersland, R. and Strøm, O. (2010) 'Microfinance Mission Drift?', World Development, 38(1), 28-36.

Rahman, A. (1999) 'Micro-credit Initiatives for Equitable and Sustainable Development: Who Pays?', World Development, 27(1), 67-82.

Reed, L. (2014) Resilience: The State of the Microcredit Summit Campaign Report, 2014. Washington, DC: Microcredit Summit Campaign [online]. Available from: http://stateofthecampaign.org/the-2014-re port-2/ [Accessed 26 February 2016].

Roodman, D. (2011) 'Does Compartamos Charge 195\% Interest?' David Roodman's Microfinance Open Book Blog, 31 January 2011 [online]. 
Available from: http://www.cgdev.org/blog/does-compartamos-cha rge-195-interest [Accessed 27 August 2015].

Roy, A. (2010) Poverty Capital: Microfinance and the Making of Development. New York: Routledge.

Smart Campaign (n.d.) The Client Protection Principles [online]. Available from: http://www.smartcampaign.org/storage/documents/smart_ca mpaign_cpps.pdf [Accessed 27 August 2015].

Smart Campaign (2013a) 'New Client Protection Certification Program Sets the Bar for Microfinance Smart Campaign Announces First "Client Protection Certified" Institutions', Washington, DC (January 24 2013) [online]. Available from: http://www.smartcampaign.org/newsa-highlights/press-releases/36-2011/757-announcing-client-protectioncertification [Accessed 27 August 2015].

Smart Campaign (2013b) Client Protection Certification Standards: January 2013 [online]. Available from: https://centerforfinancialinc lusionblog.files.wordpress.com/2013/08/certification-standards_e nglish-1-22-mb.pdf [Accessed 22 October 2015].

Smart Campaign (2014) Certification Frequently Asked Questions [online]. Available from: http://www.smartcampaign.org/certification/certif ication-frequently-asked-questions-faq [Accessed 27 August 2015].

SPTF (2012) Introduction to the SPTF Universal Standards for Social Performance Management [online]. Available from: http://www.sptf.inf o/images/designed\%20usspm\%20manual\%2010\%2015\%2012.pdf [Accessed 27 August 2015].

SPTF (2015) SP Task Force [online]. Available from: http://sptf.info/sp-ta sk-force [Accessed 27 August 2015].
Truelift (n.d.) Pro Poor Principles [online]. Available from: https://sealofe xcellence.wordpress.com/pro-poor-principles. [Accessed 27 August 2015].

Waterfield, C. (2015) 'MFTransparency is Dead ... What Does That Mean for Pricing Transparency?', NextBillion blog, 30 March 2015. [online]. Available from: http://nextbillion.net/blogpost.aspx?blogid=5363 [Accessed 27 August 2015].

Weber, H. (2002) 'The Imposition of a Global Development Architecture: The Example of Microcredit', Review of International Studies, 28 (3), 537-555.

World Bank (Committee of Donor Agencies for Small Enterprise Development \& Donors' Working Group on Financial Sector Development) (1995) Micro and Small Enterprise Finance: Guiding Principles for Selecting and Supporting Intermediaries [online]. Available from: www.enterprise-development.org/download.ashx?id= 2554 [Accessed 26 August 2015].

\section{Author Information}

Philip Mader is a research fellow at the Institute of Development Studies (IDS) in Brighton, working on financialisation, financial inclusion, debt, youth employment and state-business relations. He previously worked at the University of Basel and the Max Planck Institute for the Study of Societies. His book The Political Economy of Microfinance: Financializing Poverty (Palgrave) was published in 2015. 